\title{
TEACHING WORLD WAR I: AN EXPLORATORY STUDY OF REPRESENTATIONS OF THE GREAT WAR IN CONTEMPORARY AFRICAN TEXTBOOKS
}

\author{
DOI: http://dx.doi.org/10.17159/2223-0386/2015/n14a8 \\ Denise Bentrovato \\ Georg Eckert Institute for International Textbook Research \\ Braunschweig, Germany \\ bentrovato@gei.de
}

\section{Abstract}

World War I (WW1) is widely recognised as an event of critical significance and far-reaching consequences, a violent episode of unprecedented magnitude which affected millions of lives and which brought lasting change to the world in which we live. One hundred years after the outbreak of this global war, successive younger generations across the globe have been taught about this watershed event in world history. This paper seeks to fill a notable gap in extant research on WW1 by exploring the ways in which the history of this war is taught to Africa's younger generations through the findings of an exploratory study on representations of the Great War in recent African school textbooks. The study draws on an analysis of over 30 history and social studies textbooks from 15 different countries to investigate the core questions around which lessons on WW1 are designed across the continent, and the specific knowledge conveyed and emphasised in the answers provided to these questions. The article demonstrates efforts, found across African textbooks, to reclaim and re-centre local historical agency, experiences, and views related to WW1, while also pointing to the possibility to better valorise this part of national, African and world heritage to learn meaningful lessons for the present and the future.

Keywords: World War I; Textbooks; African history; Colonialism; Representations; Historical consciousness; African consciousness.

\section{Introduction}

In the summer of 2014, the world marked the centenary of the outbreak of World War I (WW1). This watershed event in world history occupies a significant place in public memory - a memory now boosted by countless initiatives to commemorate and educate audiences about the war, among them memorials, publications, documentaries, films, and exhibitions. 
World War I, also known as the First World War or the Great War, mainly evokes the horror of the trenches on the Western Front and thus is primarily perceived as an essentially (West-) European conflict. This is reflected in an academic historiography of the Great War which has traditionally been dominated by a Eurocentric perspective. A review of extant literature points to Africa's role, in particular, as one of the less studied aspects of WW1. For decades, Africa was neglected in narratives of WW1, the African front appearing at best as a mere "sideshow" to the war fought in Europe. ${ }^{1}$

The largely untold story of Africa in World War I is both tragic and significant. The UNESCO's General History of Africa describes it as a "turningpoint in African history", ${ }^{2}$ which affected the lives of millions of people across the continent. First of all, Africa was an important stake of WW1 insofar as imperialism and colonial rivalry among European powers had been one of the causes of the rising tensions that eventually led to the outbreak of the Great War. Secondly, the African continent was a theatre of WW1 from 1914 until after the signing of the armistice of Rethondes on 18 November 1918. Military campaigns were conducted around the German colonies of Kamerun and Togoland in West Africa (modern-day Cameroon and Togo), German South-West Africa (modern-day Namibia), and German East Africa (modern-day Tanzania, Rwanda and Burundi) - territories which, after the defeat of Germany in the war, were redistributed among the victorious powers as agreed in the Treaty of Versailles of 1919. Thirdly, Africa served as a reserve from which to massively draw men and resources critically needed for the war effort. Many were mobilised, often forcedly, to fight in Africa as well as in Europe, while people on the home-front were forced to contribute to their métropoles' war economies, for instance by surrendering foodstuffs, which caused grave shortages and increased vulnerability to deadly diseases. Africa's involvement in WW1 was highly costly. Hundreds of thousands died, and societies and their economies were severely disrupted. The war also marked a critical turning point in the relationship between Europeans and Africans. The war for ever corroded the image of the white man as superior and undefeatable. It also instilled a sense of self-awareness and sowed the seeds of revolt that would eventually lead to African countries seeking, and

1 C Koller, "Historiography 1918-Today (Africa)," 1914-1918-online, International Encyclopaedia of the First World War, ed. by U Daniel, P Gatrell, O Janz, H Jones, J Keene, A Kramer, \& B Nasson, issued by Freie Universität Berlin, Berlin 2014-10 08 (available at http://dx.doi.org/10.15463/ie1418.10426, as accessed on 20 October 2015).

2 M Crowder, "The First World War and its consequences", AA Boahen (ed.), General History of Africa, VII, Africa under colonial domination 1880-1935 (Paris, UNESCO, 1985), p. 309. 
gaining, independence. ${ }^{3}$

The relatively marginal place of this story in the strongly Eurocentric historiography of WW1 is reflected in mainstream European as well as American school textbooks and popular culture, which continue to nurture cultural bias and misconceptions among pupils by largely ignoring the devastating experience of war in Africa (and elsewhere) and by prompting students to generally view World War I "as a conflict that almost exclusively involved white soldiers fighting on European soil". 4 The widespread misconceptions on the negligible role of Africa in WW1 appear to extend to African countries themselves. A research project I conducted a few years ago on historical consciousness among young people in Central Africa found WW1 to be primarily understood as part of a "foreign history which does not concern us directly", and of which most respondents seemed to have only the vaguest understanding. ${ }^{5}$

Written against this backdrop, this article explores how Africa's education systems, understood here as important traditional vehicles of collective memory and group identity, have responded both to the longstanding marginalisation of Africa's untold story of WW1 in mainstream discourse and the concomitant increased interest, recently shown in African countries, to gaining ownership over this history and to promoting its remembrance. ${ }^{6}$ The article presents the results of an exploratory study of representations of the Great War in contemporary African textbooks, the aim being to complement international research on World War I and its teaching, and to broaden predominantly narrow western perspectives on such issues, by examining how, one hundred

3 On Africa's role in WW1, see, among others, L Catherine, Loopgraven in Afrika (1914-1918): De vergeten oorlog van de Congolezen tegen de Duitsers (Berchem, EPO, 2013); J Frémeaux, Les colonies dans la Grande Guerre: Combats et épreuves des peuples d'outre-mer (Paris, Ed, 2006); H Liebau, et al. (eds), The world in world wars: Experiences, perceptions and perspectives from Africa and Asia (Leiden, Brill, 2010); M Michel, L'Afrique dans l'engrenage de la Grande Guerre (Paris, Karthala, 2013); ME Page (ed.), Africa and the First World War (New York, St. Martin's Press, 1987); A Samson, World War I in Africa: The forgotten conflict among the European powers (London, I.B. Tauris, 2013); H Strachan, The First World War in Africa (Oxford, Oxford University Press, 2004). While such western scholars have made important contributions to the expanding scholarship on Africa in World War I, the perspectives of African intellectuals have remained peripheral.

4 SJ Foster \& R Rosch, Teaching World War I from multiple perspectives, (no date) (available at http://www. socialstudies.org/system/files/publications/se/6107/610711.html, as accessed on 20 October 2015).

5 D Bentrovato, "Narrating and teaching the nation: The politics of history, identity and education in the Great Lakes Region of Africa”, Ph.D, Utrecht, University of Utrecht, 2013.

6 Several African countries have seen the erection of monuments, the renaming of streets and squares, and the introduction of public holidays to commemorate African soldiers who fought and died during the war and to celebrate the victories gained. In Mali, for instance, one can find monuments in memory of "the Heroes of the Black Army" who fell in the battle of the Marne. In Senegal, the Journée du Tirailleur was introduced in 2004, while Place de la Gare was renamed Place du Tirailleur in their memory. Here, the colonial statue Demba et Dupont has been restored as a symbol of the heroic historical role and sacrifice of Africans for freedom in the world. 
years on, the First World War experience is taught in schools across Africa. Ultimately, this study - the first of its $\mathrm{kind}^{7}$ - draws on narratives of the First World War presented in African textbooks to offer a more transnational narrative of this war and to allow for a more global and inclusive picture of events while also prompting reflection on meaningful ways of teaching this historical topic in present-day African classrooms and beyond.

\section{Methodology}

This article places school textbooks at the centre of the analysis, viewing them as important cultural and political artefacts and as carriers of what is considered to be legitimate knowledge in any given society. The analysis draws on the established tradition of history textbook research, and pays particular attention to such artefacts' mediated narratives of the past, notably of World War I, in order to examine and contrast what is told and how in national narrations and to illuminate their role in shaping young people's historical consciousness in the present. As ample research has demonstrated, the stories that nations have chosen to tell their younger generations, and which they have conventionally transmitted through state-approved school textbooks, typically are stories conveniently and purposely selected to promote a sense of collective identity founded on a group's presumed shared history and destiny, thus making textbooks key instruments of socialisation and nation-building. ${ }^{8}$

This article aims to shed light on such processes by critically examining perspectives offered in selected school textbooks from fifteen countries in Sub-Saharan Africa on the history of World War I. The sample, encompassing thirty-three primary and secondary school textbooks, books for revision and exam preparation, and teacher guides for the subjects of history and social studies, was selected after a cursory scrutiny of over one hundred schoolbooks available at the specialised library of the Georg Eckert Institute for International

7 Overall, research on how WW1 is taught around the world is rather scarce and scattered. An exception, providing examples from Europe, America, Asia and Sub-Saharan Africa, can be found in the special issue of Historiens \& géographes, 369, 2000. Noteworthy is also the special issue of Internationale Schulbuchforschung: Zeitschrift des Georg-Eckert-Instituts für Internationale Schulbuchforschung 22(3) 2000 on "Erster Weltkrieg und Versailler Vertrag / The First World War and the Treaty of Versailles" edited by R Bendick and R Riemenschneider. Another interesting comparative research on the teaching of WW1 in Europe has been conducted by: J Müller \& A Wagner, "'Regards Croisés' - Ikonographie des Ersten Weltkrieges in aktuellen europäischen Geschichtsbüchern", Yearbook of the International Society for History Didactics, 2010, pp. 235-248.

8 See, among others: S Foster \& K (eds.), What shall we tell the children?: International perspectives on school history textbooks (Greenwich, Information Age Publishing Inc Crawford, 2006); W Marsden, The school textbook: Geography, history, and social studies (London, Woburn Press, 2001); J Nicholls, School history textbooks across cultures: International debates and perspectives (Oxford, Symposium Books, 2006). 
Textbook Research and in the author's extensive private collection. The sample included all the most recent books available in the two accessed collections that were considered relevant to this study, that is, all those which dealt, to various degrees, with WW1. Although a diachronic study would undoubtedly be worth conducting, this research, being exploratory, is limited to an analysis of contemporary African textbooks, which were published in the last two decades. ${ }^{9}$ In addition, the selection favoured textbooks produced specifically for Sub-Saharan Africa and written in accordance with national syllabuses, and included textbooks produced by national and international publishers alike (such as Macmillan, Longman, and Hatier).

With an eye to being as inclusive and diverse as possible in terms of regional coverage, care was taken to include textbooks from countries in West, Central, East and Southern Africa which are former English, French, German, Belgian, Italian and Portuguese colonies, or which were never formally occupied and colonised by European powers, notably Liberia (Table 1). At least one textbook was analysed from each of the following countries: ${ }^{10}$

- Cameroon, Ivory Coast, Liberia, Nigeria, Senegal and Sierra Leone in West Africa;

- DR Congo, Ethiopia, Kenya, Rwanda and Tanzania in Central and East Africa; and

- Angola, Mozambique, Namibia and South Africa in Southern Africa.

Table 1: List of textbooks analysed and the codes used for analysis and reference

\begin{tabular}{|l|l|c|}
\hline Country & Title & $\begin{array}{c}\text { Code used for } \\
\text { analysis and reference }\end{array}$ \\
\hline Angola & $\begin{array}{l}\text { 1. J Mendes Lopes, História da 9a Classe (Luanda, Texto } \\
\text { Editores-Leya, 2014). }\end{array}$ & ANG1 \\
\hline Cameroon & $\begin{array}{l}\text { 2. ML Tazanu et al, Ordinary Level History for Cameroon } \\
\text { Schools, 2 (Buea, ANUCAM, 2008). }\end{array}$ & CM1 \\
\cline { 2 - 3 } & $\begin{array}{l}\text { 3. R Fomenky \& MB Gwanfogbe, Histoire du Cameroun. } \\
\text { Cours Elémentaire: 3e et 4́ Années des Ecoles Primaires } \\
\text { (Yaoundé, CEPER, 1998). }\end{array}$ & CM2 \\
\cline { 2 - 3 } & $\begin{array}{l}\text { 4. R Fomenky \& MB Gwanfogbe, Histoire du Cameroun. } \\
\text { Cours Moyen: 5e et Ge Années des Ecoles Primaires (Yaoundé, } \\
\text { CEPER 1998). }\end{array}$ & CM3 \\
\hline
\end{tabular}

9 The most recent textbook sampled was issued in 2014. It is important to note that new curricula might have overtaken some of the textbooks selected for this study, although the latter might still remain in use.

10 The selected textbooks were written in English, French, Portuguese or Afrikaans. 


\begin{tabular}{|c|c|c|}
\hline \multirow[t]{2}{*}{ Dr Congo } & $\begin{array}{l}\text { 5. Une reunion de professeurs [a team of teachers], Histoire } \\
\text { 6e Primaire. Le Congo }(\mathrm{rd}) \text { en Afrique et dans le Monde. Des } \\
\text { Origines à Nos Jours (Kinshasa, New Scolot Ed, 2004). }\end{array}$ & DRC1 \\
\hline & $\begin{array}{l}\text { 6. S Longo Kazumba, Histoire classes terminales (Kinshasa, } \\
\text { New Scolot Ed, n.d.). }\end{array}$ & DRC2 \\
\hline Ethiopia & $\begin{array}{l}\text { 7. M Dinko \& M Adugna, History. Student textbook, Grade } \\
\text { 10, Revised ed. (Addis Ababa, Mega Publishing Enterprise, } \\
\text { 2005). }\end{array}$ & ETH1 \\
\hline $\begin{array}{l}\text { Francophone West } \\
\text { Africa (e.g. Ivory Coast, } \\
\text { Senegal) }\end{array}$ & $\begin{array}{l}\text { 8. Une équipe d'enseignants africains [a team of African } \\
\text { teachers], L'Afrique et le Monde. Histoire, } 3 \text { (Paris, Hatier, } \\
\text { 1995). }\end{array}$ & $\mathrm{CI} 1$ \\
\hline Ivory coast & $\begin{array}{l}\text { 9. Une équipe d'enseignants africains [a team of African } \\
\text { teachers], Histoire Geographie, } 3 \text { (Abidjan/Paris, CEDA/ } \\
\text { Hatier, 1999). }\end{array}$ & $\mathrm{CI} 2$ \\
\hline \multirow[t]{2}{*}{ Kenya } & $\begin{array}{l}\text { 10. A Gichema et al, Secondary History and government. } \\
\text { Form three students' book, } 4 \text { (Nairobi, Kenya Literature } \\
\text { Bureau/Ministry of Education, } 2011 \text { [reprinted in 2013]). }\end{array}$ & KN1 \\
\hline & $\begin{array}{l}\text { 11. A Gichema et al, Secondary History and government. } \\
\text { Form four students' book, } 4 \text { (Nairobi, Kenya Literature } \\
\text { Bureau/ Ministry of Education, } 2012 \text { [reprinted in 2013]). }\end{array}$ & $\mathrm{KN} 2$ \\
\hline Liberia & $\begin{array}{l}\text { 12. JS Guannu, A short History of the First Liberian } \\
\text { Republic. } 3 \text { (Monrovia, Star Books, 2010). }\end{array}$ & $\mathrm{L} 1$ \\
\hline Mozambique & $\begin{array}{l}\text { 13. JBH Fenhane, História } 10^{a} \text { Clase (Maputo, Diname, } \\
\text { 2002). }\end{array}$ & MOZ1 \\
\hline \multirow[t]{5}{*}{ Namibia } & $\begin{array}{l}\text { 14. G Weldon et al, MacMillan History for Southern Africa. } \\
\text { Namibia edition (Manzini/Swaziland, Macmillan Boleswa, } \\
\text { 2012). }\end{array}$ & NM1 \\
\hline & $\begin{array}{l}\text { 15. C Kotzé \& L Lang, History for Namibian schools: A new } \\
\text { perspective, Grade } 10 \text { (Windhoek, Gamsberg Macmillan, } \\
\text { 1993). }\end{array}$ & NM2 \\
\hline & $\begin{array}{l}\text { 16. P Ranby, Go for History, Grade } 9 \text { (Windhoek, } \\
\text { MacMillan Namibia, 2012). }\end{array}$ & NM3 \\
\hline & $\begin{array}{l}\text { 17. D Goosen \& A Du Preez, Understanding History in } \\
\text { context, Grade } 9 \text { (Windhoek, Longman Namibia, } 2007 \\
\text { [reprinted in 2011]). }\end{array}$ & NM4 \\
\hline & $\begin{array}{l}\text { 18. B Cloete \& C Dugmore, Discover History. Grade } \\
\text { 9, learner's book (Sandton, Heinemann International } \\
\text { Southern Africa, 2011). }\end{array}$ & NM5 \\
\hline Nigeria & $\begin{array}{l}\text { 19. A Bakare, A Belgore \& E Harrison, Social studies for } \\
\text { Primary Schools, Book Five (Onikan, Farafina Educational, } \\
\text { 2008). }\end{array}$ & NG1 \\
\hline
\end{tabular}




\begin{tabular}{|c|c|c|}
\hline \multirow[t]{4}{*}{ Rwanda } & $\begin{array}{l}\text { 20. E Bamusananire et al, Primary social studies, Pupil's } \\
\text { book } 6 \text { (Kigali, Macmillan Rwanda, } 2006 \text { [reprinted in } \\
\text { 2010]). }\end{array}$ & RW1 \\
\hline & $\begin{array}{l}\text { 21. C Gahima et al, The History of Rwanda. A participatory } \\
\text { approach. Teacher's guide for Secondary Schools (Kigali, } \\
\text { Republic of Rwanda, Ministry of Education, National } \\
\text { Curriculum Development Centre, 2010). }\end{array}$ & RW2 \\
\hline & $\begin{array}{l}\text { 22. E Bamusananire \& D Ntege, New Junior Secondary, } \\
\text { History Book } 2 \text { (Kampala, Netmedia Publishers, n.d.). }\end{array}$ & RW3 \\
\hline & $\begin{array}{l}\text { 23. E Bamusananire \& D Ntege, New Junior Secondary, } \\
\text { History Book } 3 \text { (Kampala, Netmedia Publishers, n.d.). }\end{array}$ & RW4 \\
\hline Sierra Leone & $\begin{array}{l}\text { 24. JAD Alie, A new History of Sierra Leone (Oxford, } \\
\text { Macmillan, } 1990 \text { [reprinted in 2005]). }\end{array}$ & SL1 \\
\hline \multirow[t]{7}{*}{ South Africa } & $\begin{array}{l}\text { 25. J Bartels, P Ellis \& P Olivier, Shuters History, Grade } 11 . \\
\text { Learner's book (Pietermaritzburg, Shuter \& Shooter, } 2006 \\
\text { [reprinted in 2011]). }\end{array}$ & SA1 \\
\hline & $\begin{array}{l}\text { 26. J Bartels, P Ellis \& P Olivier, Shuters History, Grade } 11 . \\
\text { Teacher's guide (Pietermaritzburg/ Cape Town/ Randburg, } \\
\text { Shuter \& Shooter, 2006). }\end{array}$ & SA2 \\
\hline & $\begin{array}{l}\text { 27. L Sikhakhane et al, History, Grade 11. Educator's guide } \\
\text { (Overport, Durban, New Generation Publishers, 2007). }\end{array}$ & SA3 \\
\hline & $\begin{array}{l}\text { 28. L Sikhakhane et al, Geskiedenis, Graad 11. Leerderse } \\
\text { boek (Overport, Durban, Nuwe Generasie, 2009). }\end{array}$ & SA4 \\
\hline & $\begin{array}{l}\text { 29. J Earle and A Briggs, Social Sciences Today, Grade } 8 . \\
\text { Learner's book (Pinelands, Cape Town, Maskew Miller } \\
\text { Longman, 2008). }\end{array}$ & SA5 \\
\hline & $\begin{array}{l}\text { 30. J Bottaro et al, Oxford successful social sciences. Grade 8, } \\
\text { learner's book (Goodwood, Cape Town, Oxford Univ. Press } \\
\text { Southern Africa, 2010). }\end{array}$ & SA6 \\
\hline & $\begin{array}{l}\text { 31. J Bottaro et al, Oxford - Op soek na sosiale wetenskappe. } \\
\text { Graad 8, leerdersboek (Goodwood, Kaapstad, Oxford Univ. } \\
\text { Press Southern Africa, 2008). }\end{array}$ & SA7 \\
\hline \multirow[t]{2}{*}{ Tanzania } & $\begin{array}{l}\text { 32. E Nyema \& A Ngwilizi, History for Primary Schools, } \\
\text { Standard } 6 \text { (Dar es Salaam, Readit Books, 2009). }\end{array}$ & $\mathrm{TZ} 1$ \\
\hline & $\begin{array}{l}\text { 33. S James, African History from } 19^{\text {th }} c .-21^{s t} c . \text { A.D. for } \\
\text { Secondary Schools, Forms III and IV (Dar es Salaam, The } \\
\text { General Publishing House, 2008). }\end{array}$ & TZ2 \\
\hline
\end{tabular}

Informed by international scholarship on textbook research, ${ }^{11}$ the analysis of the sample presented in the next sections scrutinises textbook content related to WW1 with the purpose of identifying general trends and patterns in the various ways this historical topic is approached across Sub-Saharan Africa. A first level of analysis examines textbook content in relation to the

11 See, among others: J Mikk, Textbook: Research and writing (Frankfurt am Main, 2000); J Nicholls, "Methods in school textbook research", International Journal of Historical Learning, Teaching and Research, 3(2), 2003, pp. 1-17; F Pingel, UNESCO guidebook on textbook research and textbook revision (Paris/Braunschweig, UNESCO/ GEI, 2010); F Pingel, The European home: Representations of $20^{\text {th }}$ century Europe in history textbooks (Strasbourg, Council of Europe, 2000). 
contextualisation and coverage of the war, prominent overarching questions and issues raised, and didactic approaches adopted to teach this subject matter. A deeper content analysis subsequently delves into the specific knowledge conveyed and emphasised in providing answers to the core questions around which lessons on WW1 are designed and does this through an analysis of textbook representations of two main themes in relation to WW1: "The world at war" and "Africa at war". More specifically, the study investigates how textbooks engage with historical debates and controversies surrounding the war, including its origins and causes, the issue of responsibility for its outbreak and escalation as well as its consequences, and how they position Africa and the individual nations within the history of this war. It thereby seeks to distil the facts, dates, personalities and sites that carry particular resonance in African textbook narratives and the conceptual categories and interpretative frameworks they adopt. While it does not claim to be comprehensive, the sample undoubtedly provides telling insights into such questions.

\section{General trends in textbook content and pedagogy}

The analysis of the textbooks that were sampled for this study exposed several general trends in relation to the teaching of WW1 in present-day African classrooms. Broadly, the study found the Great War, variously treated as a theme in national, African or world history, to hold a marginal place in the analysed textbooks. Most of the textbooks dedicate one or two pages to WW1 and some only a few sentences. ${ }^{12} \mathrm{~A}$ review of the predominantly cursory coverage of this theme in African textbooks further revealed a certain agreement on the main topics and significant questions that should be addressed in African classrooms with regard to the First World War. Pupils across Africa are expected to understand the causes, course and consequences of the war, specifically in relation to their own country, and to distil the main achievements and weaknesses of the peace settlement that ended the war. Similarities and differences in these respects will be analysed in more detailed in the following sections.

From a pedagogical perspective, the analysis of the topics dealt with in African textbooks exposed the predominance of a chronological and eventbased approach in teaching the history of WW1, and a focus on political

12 The negligible coverage of African involvement in WW1 in scholarly work on African history is manifest in Joseph Ki-Zerbo's Histoire de l'Afrique Noire, a popular reference work used in schools across the African continent, which dedicates only a single line to the topic. J Ki-Zerbo, Histoire de l'Afrique noire: D'hier à demain. (Paris, Hatier, 1972). 
and military aspects of the war. It is largely a conventional "history from above" that is taught across Africa - a history of great men and great battles. Conversely, human aspects of the war and the experiences of common soldiers and civilians are largely neglected, while attention to social, economic, and cultural aspects of WW1, typical of a "history from below", is mainly shown in relation to the consequences of the war, notably in Africa. Additionally, congruent with a traditional approach to teaching history, which seems to be widely embraced across the continent, the sample of African textbooks used for this study shows the predominance of authored text when dealing with the Great War, with the textbook narrative being accompanied at most by one or two visual aids, such as timelines of main events and maps, and with teaching and learning activities centred primarily on assessing factual knowledge as presented in the narrative provided by the textbook authors.

The most notable exceptions to this general trend in history pedagogy across Sub-Saharan Africa were found in South African textbooks, which appear by far the most modern both in their presentation and their didactic approach to the subject. Contrary to most other textbooks analysed, the South African textbooks are singularly dominated by a methodology centered on the presentation of primary and secondary sources as evidence to be questioned in order to address topics of historical debate from different perspectives. The approach adopted in the South African textbooks is geared towards nurturing critical thinking and developing historical skills and understanding of disciplinary concepts, such as chronology and time, cause and effect, continuity and change, links between past and present, and historical empathy, e.g. with soldiers who fought in WW1 and "with people who were colonised and who were victims of imperialism". ${ }^{13}$ The South African textbooks are also characterised by a largely thematic approach and by particular attention being paid to social and cultural history and a "history from below", with its emphasis on human experiences and emotions and on a study of the war from the perspective of ordinary people as well as on post-war commemorative cultures. Besides drawing attention to political leaders and their choices, they expose students to the combatant and the civilian experience of the conflict and their suffering during the war, by abundantly using such powerful sources as diaries and poems as well as visual representations of the war such as photos, drawings and paintings.

13 SA1:24 (See code Table 1) 


\section{Textbook representations of "the world at war"}

A deeper analysis of specific textbook content points to further trends and patterns in teaching the First World War across Sub-Saharan Africa. This section presents an overview of how African textbooks describe and explain the Great War in relation to three fundamental questions, namely: Why and how did the war break out? How was it conducted? And what were its consequences?

\section{The causes of the war}

In relation to the causes of the First World War, multiple factors - military, political, economic - are typically mentioned in the African textbooks analysed. The textbooks trace the fundamental cause of the war back to increasing European rivalry for power. They commonly list factors such as the alliance system, imperialism and colonial rivalry, economic competition, growing militarism and the arms race, and nationalism. In particular, they highlight national rivalries between Germany, France and Great Britain, as well as in the Balkan region. Quite singularly, the textbooks from Tanzania, Mozambique and Angola, all countries with a post-colonial history marked by the embracing of a socialist ideology, are characterised by attributing the main causes of WW1 to capitalism and the rise of competition for new markets among industrial capitalist and imperialist countries in Europe, while also showing particular attention to the labour movement and the Second International and its fight against colonialism and militarism at the time. ${ }^{14}$

In quite an unusual manner across Africa, South African history textbooks at senior level explicitly present the origins of WW1 as a matter of historiographical debate and controversy and provide various sources hinting at "some of the most important causes suggested by historians", thereby encouraging pupils to reflect on the reasons of disagreement among scholars. As part of the exploration of the context and causes of WW1, South African textbooks at this educational level propose a case-study on "Kaiser Wilhelm II and German militarism", directing pupils to different historical sources (British newspapers, French cartoons, and pictures) to address this major topic of debate and build arguments on the Kaiser's imperialistic ambitions and his

14 The Tanzanian book defines WW1 as a "crisis in the capitalist system" and as "imperialistic fighting", with imperialism being described in the Mozambican textbook as a later phase of capitalism. TZ2: 87, 93; MOZ1:33, 50 (See codes Table 1). 
responsibility for the war. ${ }^{15}$ In addition to promoting historical knowledge and disciplinary skills, in South Africa the teaching of the causes of WW1 is explicitly expected to nurture critical thinking in combination with social and civic norms, values and attitudes among pupils, including recognition of the risks of interstate rivalry and competition, of the value of patriotism and the dangers of extreme nationalism, and of leaders' influence on society and the perils of "unsound leadership". ${ }^{16}$ In an exercise in critical thinking and problem solving, one South African textbook further invites pupils to reflect whether in 1914 "war was the only option" or could instead have been averted. ${ }^{17}$

\section{The course of the war}

The African textbooks analysed typically draw attention to the course of the war that broke out as a result of the existing alliance system. They outline the warring parties, the theatres of war, and the weapons and tactics used. They underscore the uniqueness of the First World War, described as "the biggest and most destructive war the world had ever seen"18 - a war which "reached almost all the peoples of the earth". ${ }^{19}$ One Namibian textbook explains that "these years were the years of empire and colonies" and that "any war in Europe meant a world war". For this reason, it concludes, "peace in Europe was of great importance to the rest of the world" ${ }^{20}$

The Western Front is usually presented as the most decisive front and the scene of "senseless slaughter". ${ }^{21}$ One textbook widely used in Francophone Africa, and published by Hatier, one of the top French publishers of educational media, includes a few sources on the fighting conducted on this front, illustrating different dimensions of war experience by complementing images of enthusiastic and patriotic French war mobilisation with sources conveying the harsh reality of life in the trenches. ${ }^{22}$ Similarly exposing pupils to such complexities, the South African textbooks pay considerable attention to the power of propaganda during mobilisation in Britain, Germany and USA, showing countries on both sides of the conflict depicting their

15 SA1:38-39 (See code Table 1).

16 SA2:30 (See code Table 1).

17 SA5:165 (See code Table 1).

18 NM1:1(See code Table 1).

19 DRC1:129 (See code Table 1).

20 NM2:155 (See code Table 1).

21 SA6:152-153 (See code Table 1).

22 CI1:63-65 (See code Table 1). 
respective involvement in the war as a necessary and patriotic defensive struggle against merciless aggressors. Their focus is on contextualising and carefully examining iconographic objects, such as posters urging citizens to enlist for WW1, in order to discern their political motives and bias and their persuasive techniques, while also expecting pupils to reflect on the use of propaganda today. At the same time, the South African textbooks familiarise pupils with soldiers' wartime experiences during WW1, encouraging them to empathise with the combatants through the use of testimonies and pictures giving impressions of life in the trenches. In line with the "cultural" turn of the historiography of WW1, they examine sensory and emotional aspects of wartime experiences, stimulating pupils to think and feel about a distant past, for instance by conveying vivid images of the sickening "smell of rotting bodies" and poison gas, the "unbearable" noise of shelling, and the "sights and sounds of soldiers dying on all sides". They also address the question of soldiers' consent or coercion to fight by highlighting the pressure to enlist, the severe discipline, and the punishment to which soldiers were subjected for not following orders. ${ }^{23}$ Furthermore, the South African textbooks draw attention to artistic responses to WW1, quoting popular war literature, including war poets Wilfred Owen and Siegfried Sassoon, to show "the horror and sorrow of war" ${ }^{24}$ and to demystify the belief spread by propaganda that "it was good and proper to die for your country". ${ }^{25}$ Against this backdrop, pupils in South Africa are encouraged to reflect on their own views and attitudes towards war, and, more specifically, on such issues as conscription and conscientious objection. $^{26}$

Overall, in contrast to many other textbooks used across Sub-Saharan Africa, which simply present the course of the war predominantly as a list of military operations and victories and defeats, the Francophone and especially the South African textbooks mentioned above seek to bring complexity and multiperspectivity to the way the course of WW1 is taught. They present and question sources that offer different perspectives on the war and propose exercises in historical empathy, asking pupils to imagine how they would have felt about certain actions if they had been on one or the other side of the conflict. ${ }^{27}$

23 SA5:167-170; SA6:152-154; S7:154 (See codes Table 1).

24 SA5:177 (See code Table 1).

25 SA5:170 (See code Table 1).

26 SA5:161 (See code Table 1).

27 SA5:171 (See codes Table 1). 


\section{The peace settlement and the consequences of the war}

With regard to the peace settlement that followed Germany's surrender, the textbooks surveyed show pupils across Africa to be typically expected to know about the major participants at the negotiation table and their conflicting interests, the terms of the peace, and its achievements and weaknesses.

The textbooks usually offer a critical and mostly negative assessment of the peace process. They show a general understanding of the peace treaty as an important destabilising factor in the aftermath of the war, which ultimately sowed the seeds of a new global war. Textbooks from former German colonies in particular, i.e. Namibian, Rwandan and Cameroonian, highlight the imposed and therefore unfair nature of the treaty of Versailles, and underscore the harshness of this treaty, which greatly punished and humiliated Germany, causing great suffering to its people and consequent resentment. ${ }^{28}$ In relation to the issue of war guilt, while several books hint at Germany's overwhelming share of the blame, the African textbooks analysed show a certain consensual view on shared responsibility among Western, and especially European, powers. They frequently address the controversial issue of responsibility for the war by extending the blame for the conflict indistinctly to "the great powers", or the "imperialist" or "capitalist" powers, and, more specifically, to "the two opposing camps" led by Britain and Germany, all equally condemned in these textbooks for threatening world peace. By leaving this controversial issue to discussion, South African textbooks once again show a distinct approach to teaching World War 1. At junior level, they explicitly encourage pupils to question the War Guilt Clause and discuss "whether it was fair to blame Germany for causing the war", and, more generally, whether it is "possible that only one party is guilty in any conflict" ${ }^{29}$

The textbooks often conclude their discussion on WW1 by indicating some of the consequences of a war which, according to one textbook, "changed the world" fundamentally. ${ }^{30}$ Among other things, the textbooks frequently draw attention to the devastation caused by the war, highlighting its massive human and material cost. Several books illustrate a number of social and cultural consequences of the war as well. They refer to a contestation of pre-war values after WW1 and elaborate on the change of norms resulting from a "profound traumatism" in European societies caused by the war. ${ }^{31}$ A few textbooks

28 NM1:9; NM2:148-149; RW4:23; CM1:286-288 (See codes Table 1).

29 SA6:149; and SA7:159, respectively (See codes Table 1 ).

30 NM1:2 (See code Table 1).

31 CI1:74 (See code Table 1). 
mention a decline of such beliefs as the supremacy of western civilisation, with one Namibian book arguing that after WW1 "people now saw that Europe was not superior to the rest of the world". ${ }^{32}$ They also point to a concomitant triumph of pacifist ideas across Europe in the face of the horrors of the war. The Francophone textbook by Hatier, for instance, presents an extract from a French anti-war document from 1917, which conveys a pacifist message to pupils by stressing that "if you were to tell soldiers that there will be another war, they will reply 'It is not for this that we fought!". ${ }^{33}$ Considerable notice is further taken of how WW1 challenged gender roles and norms in Europe, changing the role of women in society as a result of their vital contribution to the war effort. ${ }^{34}$ In their attempts to link the past and the present while framing discussions in a human rights discourse, South African textbooks in particular encourage pupils to think about and discuss the rights and opportunities women have in the world today, especially in South Africa, a country where voting rights by non-white women were attained as late as 1994, and where high rates of violence against women exist. ${ }^{35}$

In relation to the aftermath of WW1, again none but the South African textbooks deal with the issue of remembrance. Textbooks used in this country examine how WW1 has been remembered, and more generally encourage pupils to reflect on the relevance and importance of remembering and on effective ways of doing so.

\section{Textbook representations of "Africa at war"}

Beyond describing how WW1 played out in Europe in particular, the African textbooks analysed in this study often address, in varying degrees, the central questions of why and how the war affected people in Africa, and in respective countries more specifically.

\section{Explaining Africa's involvement in $W W 1$}

As hinted at earlier, the African textbooks sampled typically present WW1 as a European war, or at most as an international event, which had not spared

32 NM1:3 (See codes Table 1).

33 CI1:78 (See code Table 1).

34 For example NM1:3; CI1:74 (See codes Table 1).

35 SA2:157 (See code Table 1). 
the colonies. Described in one book as a "purely European affair", ${ }^{36}$ WW1 is widely reported to have extended to Africa, turning the continent into one of the battlegrounds of a disastrous war.

One Cameroonian schoolbook elaborates on the causes of Africa's involvement, highlighting the Allies' wish to take over Germany's colonies and exploit their resources, among other things "under the pretext of rescuing the indigenes from the harshness of German rule". ${ }^{37}$ It also mentions the Allies' wish to use the conquered colonies as a "bargaining weapon" in case of occupation of European territories by the enemy, and to "attack and defeat the Germans wherever they were found in the world". ${ }^{38}$ The textbooks often explain the involvement of African people in a foreign war by stating the simple reason that, at the time, Africans were, for the most part, colonial subjects of European powers embroiled in conflict, who, on account of their subordinate status, were expected to join the fighting on the side of their colonial masters. The Cameroonian schoolbook mentioned above points out that, "the war broke out in Europe and did not concern the people of Cameroon in any direct way. Fighting started in Cameroon mainly because the territory was a colony of Germany, an enemy to Britain and France." 39 Similarly, on the question of "why South Africa invaded Namibia to wage war against the Germans", ${ }^{40}$ a Namibian textbook explains that, "Namibia was a German colony and thus joined the war on the side of Germany. South Africa had been a British colony and therefore joined the war on the side of Britain. This meant that Namibia was at war with South Africa." 41

The textbooks underscore that Africa eventually became greatly involved in the war, having been both a battleground and a crucial reserve of human and material resources needed to support the European war effort.

\section{Africa as a battleground}

In the textbooks analysed in this study, Africa is presented, first of all, as a battleground, a "terre des combats", during WW1. These books describe, with varying degrees of detail, how the war was fought on the African continent, outlining strategies and tactics, and main frontlines and battles.

36 CM1:176 (See code Table 1).

37 CM1:49 (See code Table 1).

38 CM1:176 (See code Table 1).

39 CM1:49 (See code Table 1).

40 NM3:47 (See code Table 1).

41 NM3:58 (See code Table 1). 
Some of them, such as the Francophone textbook by Hatier, present maps of Africa, distinguishing neutral countries, the colonies of the Allies, and German territories, and showing troop movements and attacks. The same textbook presents an overview of battles fought in Africa, including a timeline of Germany's defeats in each of its former colonies. ${ }^{42}$

The authors of this textbook dedicate a few lines to each of the war fronts in Western, Southern and Eastern Africa, respectively. They start by reporting the quick surrender of the "small and badly defended" Togo in West Africa, and speak of the tougher resistance presented by Cameroon until the retreat and surrender of German troops. ${ }^{43}$ The Cameroonian textbooks themselves elaborate on the course of the war in this country, indicating that the "German resistance was very stiff" and that the Germans, although outnumbered, were "not easily defeated" in Cameroon. ${ }^{44}$

The Francophone textbook goes on to report South Africa's conquest of German South West Africa on behalf of Britain. ${ }^{45}$ A Namibian textbook itself recounts how, after an initial phase during which "the Germans and South Africans seemed to be equally courageous and skilled in war," "South Africans ... slowly began taking over every corner of the colony". ${ }^{46}$ This same textbook mentions the fate of German prisoners of war in Namibia after the defeat of German troops by South African forces - of which no mention is however found in the South African textbooks themselves. The book explains that in Lüderitz, "the whole civilian German population was captured and sent to South Africa to be interned", condemning this as "an illegal act under international law since only soldiers can be interned in this way". ${ }^{47}$

The Francophone textbook finally describes the long guerrilla campaign that was conducted by German East Africa (Tanganyika) when confronted with "the strength of its French, British, Belgian and South African opponents". The authors underscore the great military success of the guerrilla tactic by highlighting that, "at the time of the armistice of Rethondes [which officially ended the war], the colony remained undefeated". ${ }^{48}$

The experience of war in Central Africa, an area that had not been spared by WW1, appears to be largely neglected in the overview presented in the

42 CI1:66-67 (See code Table 1).

43 CI1:66 (See code Table 1).

44 CM1:50-51 (See code Table 1).

45 CI1:66 (See code Table 1).

46 NM5:64-65 (See code Table 1).

47 NM5:64 (See code Table 1).

48 CI1:66 (See code Table 1). 
textbooks from outside this region. In relation to this region's war involvement, a Rwandan textbook itself speaks of the "insignificant" German efforts against the offensive launched by the numerically superior Belgo-Congolese forces, explaining that "in no time the Congolese forces had reconquered the Lake Kivu" after Germany's invasion. ${ }^{49}$ Similarly, a Congolese textbook reports the "crushing superiority" of the Allies in this part of the world. ${ }^{50}$

Remarkably, in the description of the battles fought on African soil, it is, at times, the Europeans, notably "the Germans, the French, the British and the Belgians", who appear as the main agents in the fighting. At other times, it is the colonies themselves that are presented as the protagonists - who fought, resisted and surrendered.

\section{Africa's war efforts: The participation of Africans in WW1}

In describing Africa's involvement in World War 1, the African textbooks analysed typically highlight the indigenous population's direct and multifarious participation, willing or not, in a war that had reached Africa's soil.

Across the textbooks, different nuances are used to recount the entry of African colonies into the war. One textbook from Tanzania, for instance, states that people in the colonies had "joined" [emphasis added] the war to "support" and "protect" the colonial masters. ${ }^{51}$ This particular formulation, including the use of the active voice, to describe Africans' involvement in WW1 on the side of their respective "métropoles" leaves room to infer the colonies' voluntary participation in the war efforts of colonial European powers. Hinting at a certain level of pressure to engage in the war, one South African textbook explains that people in territories that were part of colonial empires were "expected to help". ${ }^{52}$

Elsewhere an emphasis is placed on the exploitative and opportunistic nature of the employment of Africans in a war that was not theirs. According to an Ethiopian textbook, "colonial powers 'used' Africa's resources and Africans to support 'their' war efforts" [emphasis added]..$^{53}$ Similarly, a Namibian book explains that "the colonies... also suffered, as the colonisers used their raw

49 RW2:78 (See code Table 1).

50 DRC2:165 (See code Table 1).

51 TZ2:87, 91 (See code Table 1)

52 SA6:158 (See code Table 1).

53 ETH1:118 (See code Table 1). 
materials and people for the war". ${ }^{54}$ The authors of the Francophone textbook by Hatier echo the argument on the exploitation of the colonies in a foreign war by suggesting that "to the African combatants, the war was a 'matter of the whites': it did not concern them directly; and many had a poor understanding of the stakes". ${ }^{55}$ One Rwandan textbook further underlines the forceful and involuntary nature of African participation in WW1, stating that "both sides 'forced' Africans to fight for them" emphasis added. ${ }^{56}$ Several schoolbooks add that Africans were not only forced to fight "for" the European powers, but also forced to fight for them "against each other", thus affecting relationships between neighbouring African countries at the time. A Tanzanian textbook explains that "the British, French and Belgian colonies were fighting against the German colonies", and that Tanganyika, more specifically, "had to' fight against Kenya and Uganda that were under the British rule" emphasis added. ${ }^{57}$

In describing Africans' involvement in WW1, the textbooks generally refer to the massive recruitment of hundreds of thousands of Africans who "fought alongside their colonial masters", either on African soil or in Europe, ${ }^{58}$ as soldiers, as "carriers of heavy war loads", ${ }^{59}$ or as "scouts, guides and interpreters", "carrying out the sabotage of facilities" and "obstructing the enemy party from making use of their land or any available resource like water" - thus critically contributing to the destruction of their own or other peoples' country. ${ }^{60}$ Stressing the important, although subordinate, role of Africans in the war efforts, a Congolese textbook emphasises that "the socalled French, Belgian and British troops, put in lines, consisted of African recruits, except for the officers" ${ }^{61}$ Similarly, a Cameroonian textbook explains that "in some areas like in Togoland, they did the fighting alone, though under European command". ${ }^{62}$

The Francophone textbook by Hatier draws particular attention to the methods of recruitment in Africa. It points especially to the frequent use of force for this purpose, explaining that "recruitment, in some regions, such as in Ivory Coast, took the form of real man-hunting". ${ }^{63}$ In a section on "Africa

54 NM1:4 (See code Table 1).

55 CI1:66 (See code Table 1).

56 RW1:51 (See code Table 1).

57 TZ2:92, 87 (See code Table 1).

58 CM1:177 (See code Table 1). Across the textbooks, different figures are provided as to the exact number of Africans who participated in the war effort.

59 RW2:74 (See code Table 1).

60 CM1:51 (See code Table 1).

61 DRC2:165-166 (See code Table 1).

62 CM1:177 (See code Table 1).

63 CI1:66 (See code Table 1). 
in the war", this textbook reports an extract from a colonialist novel published in the early 1920s, titled La Randonnée de Samba Diouf, telling the story of a young Senegalese who was forcibly mobilised to fight in the European trenches in support of France's war efforts. The textbook reproduces a central scene in the novel, in which the colonial administrators demand that local chiefs provide a quota of men - a collaboration omitted in other African textbooks, - and motivate the villagers by presenting their participation in the war as a form of "gratitude" for the "bienfaits" of French colonisation, including freedom from war and slavery, and by promising advantages to the recruits. ${ }^{64}$

The Francophone textbook also draws attention to the hardship suffered by the tens of thousands of African recruits that were sent to Europe to fight and die in the trenches, and highlights the bravery of these soldiers by suggesting that the hardship they experienced during the war was no reason for them to surrender. Its authors emphasise that "everywhere their courage and loyalty aroused the admiration of their officers". ${ }^{65}$ Similarly, one Cameroonian textbook stresses that "Europeans' respect for Africans increased after watching the bravery with which the Africans fought in the war". ${ }^{66}$

Some textbooks further underscore the fact that, although recruitment became widespread in Africa, concerns existed in Europe about waging war in the colonies and employing African troops for fear of compromising the authority of the white people. A Rwandan teacher guide explains that such concerns were based on a wish "not ... to expose the faults and weaknesses of the white man to the Black people" because "the future of colonial Africa depended on the esteem of the Black people towards Europeans". The authors suggest that "the white man would not in any case be seen to be defeated or confused" and that "at all costs the Black people ... should never be given an opportunity to defeat or kill white people". ${ }^{67}$

\section{The role of local communities: A courageous war effort between loyal collaboration and patriotic resistance}

Several textbooks, which address WW1 as part of national history, elaborate on the specific position and role of the country's own people in

64 CI1:61 (See code Table 1).

65 CI1:66 (See code Table 1).

66 CM1:178 (See code Table 1).

67 RW2:74-75 (See code Table 1). 
the war opposing European powers. Rwandan and Tanzanian textbooks, for example, refer to the collaboration of their respective country and people with Germany. Congolese and South African textbooks instead exalt the role of their respective soldiers in support of the Allies wherever they were needed, telling stories of bravery, heroic sacrifice, and great loss, and honouring the fallen. Namibian and Mozambican textbooks, for their part, focus on the local opposition and resistance against their respective colonial administration during WW1. Finally, Cameroonian textbooks mention internal divisions among the colony's peoples as they sided with different camps.

\section{Loyal support to the métropole}

The examination of textbooks from countries that had fought on either side of WW1 found a frequent emphasis on the loyal support given by the former colonies to their respective métropoles and their allies during the war.

With regard to cases of collaboration with Germany, Tanzanian textbooks mention that "Tanganyika fought on the side of the colonial masters, defending the Germans", ${ }^{68}$ and speak of the role of local soldiers, the askari - African troops whose role in WW1 is greatly present in Tanzanian public memory as manifested in the "Askari Monument", a famous statue located at the very centre of downtown Dar es Salaam, former capital of German East Africa. Rwandan textbooks also provide details on the loyal collaborative role of Rwandans on Germany's side, maintaining that King "Musinga did all that was possible to help Germans" by supplying soldiers and foodstuffs. ${ }^{69}$ When further recounting the surrender of Rwandan troops after the conquest of Kigali by the Belgians, a Rwandan teacher guide highlights a general sense of nostalgia for the time of German presence in the country, suggesting that, "when the Germans left the country, they were still well appreciated, as a whole, by the population" and that "King Musinga, in particular, still longed for his friends, the Germans, until his last days" ${ }^{70}$

A perhaps even stronger emphasis on the loyal support given to the former colonial masters during the war was found in textbooks from countries that had fought on the side of the Allies. In textbooks from the DR Congo, the Congolese vital contribution to military operations and successes in Africa occupies a prominent place in the narrative of the war - a contribution the

68 TZ1:2-3 (See code Table 1).

69 RW3:79 (See code Table 1).

70 RW3:80 (See code Table 1). 
memory of which is ingrained in the names of the streets that run through Congo's capital Kinshasa, a town which also recently saw the establishment of a memorial at the round-about of rue Force Publique [the colonial army] to pay tribute to the Congolese war veterans. Congolese textbooks, perhaps more than any other, take pride in the role of the colonial army of a "thriving" Belgian Congo in defending the country's territory from enemy attacks through which German troops had violated Belgium's pledge for neutrality, as well as in assisting, in important ways, the Allies on the African Front. One of the textbooks celebrates Congolese achievements on the battlefield, recounting that, during WW1, "the Force Publique succeeds not only in opposing the invaders but also in helping the British in the East, where it gains the victory of Tabora in $1916 \ldots$ and in helping France in Cameroon ... where it participates in the taking of Yaoundé (1916)".$^{71}$

A textbook from Sierra Leone also briefly mentions the loyal support of the country, and more specifically of its dominant community, the Krio, given to the British colonial rulers, through the recruitment of "the King's Own Creole Boys" who were called upon "to fight, and if possible die, for our "Gracious King and good old England'" ${ }^{72}$ Across the border, a textbook from Liberia, which together with Ethiopia was the only free African country at that time, hints at Liberia's declaration of neutrality and its later participation in WW1 as a result of persuasion by the United States, Liberia's closest ally, upon its entry to the conflict in 1917. Conveying a sense of limited agency of Liberians in taking this decision, the author simply states that Liberia "was persuaded by America to enter the war and so she did". ${ }^{73}$

The South African textbooks, for their part, stress the loyal and committed involvement of this former settler dominion in WW1 by highlighting the mass voluntary participation of over 160000 South Africans in the war and their deployment in South West and East Africa and in the trenches on the Western Front on the side of Britain, and this despite the resistance of some Afrikaners to fighting on the British side due to having fought against them only a decade earlier in the South African War. ${ }^{74}$ Stressing the contribution of non-white South Africans as well, one textbook emphasises that at the time "the government did not want to give weapons or military training to black

71 DRC1:129 A similar focus can be found in DRC2:165 (See codes Table 1).

72 SL1:168 (See code Table 1).

73 L1:71 (See code Table 1).

74 One Namibian textbook refers to the decision of South Africa's Boer leaders to support Britain as "surprising", and traces this support to the Afrikaners' "grateful[ness]" towards the "remarkably generous [British] victors" and to their loyalty, admiration and confidence towards "the mighty British Empire". NM5:63-64 (See code Table 1). 
soldiers" and that, in spite of this, "more than 80000 black South Africans volunteered for service in non-fighting roles" as recruits in the South African Native Labour Contingent (SANLC). The textbooks further report two iconic events that tragically marked South Africa's heroic participation in WW1 and the supreme sacrifice and exceptional acts of bravery of both white and black South Africans fallen while serving overseas. They mention the valour and victory of (white) South Africans at the "fierce" and costly Battle of Delville Wood in 1916, "one of the great battles on the Western Front", which was fought as part of the allied offensive on the Somme. They also mention the "tragic" sinking of the troopship SS Mendi by a British vessel in the English Channel in 1917 and the death of hundreds of (black) South Africans, highlighting that "the ship which caused the accident did not even stop to pick up survivors" and underscoring the troops" "bravery as they faced death". Once again showing their uniqueness across Sub-Saharan Africa, in relation to these and other tragedies of WW1 South African textbooks singularly address the issue of remembrance, indicating the existence of memorials, memorial services, exhibitions, as well as poems, songs and oral tradition to honour the soldiers and their heroic acts.

\section{Betrayal and resistance}

The above mentioned emphasis on African attitudes of loyalty towards the colonial masters during WW1 starkly contrasts with the picture depicted in textbooks from other countries, which instead focus on reporting cases of desertion and betrayal in the rival camp of the conflict. This is the case in one textbook analysed for Namibia, which refers to the role of this colony's local population in a corner of Africa where, as the textbook by Hatier points out, "the white" had refused to "employ black soldiers because they feared treason". ${ }^{75}$ This Namibian textbook mentions the notable position of the Herero, a community which a few years earlier had been victim of what is today widely considered to have been the first genocide of the twentieth century. The authors recount that the Herero "deserted their German employers" while chief "Samuel Maharero sent his best Herero soldiers to help the South Africans". In a rather emotive tone, the authors then imagine how "it must have been a special moment for the Herero to see their enemies defeated"

75 CI1:66 (See code Table 1). 
when they "saw the German flag come down over Windhoek" following their defeat. $^{76}$

Similarly, a textbook from Mozambique, a country whose peoples and resources were mobilised to support Portugal's war effort, focuses on two iconic instances of anti-colonial resistance that took place in 1917 and which were sparked by Portugal's involvement in WW1. Its author describes the unprecedented rebellion triggered by Portugal's victimisation of the Barue peoples in 1917 - a revolt caused by the introduction of compulsory, nonremunerated and abusive labour to build a roadway in Barue territory for the purpose of recruiting thousands of African soldiers and carriers to fight in German East Africa. Against the backdrop of increased exploitation, oppression and abuse, and of a loss of the active population that led to grave famines, the textbook recounts how, as "a great example of patriotism", local internal divisions at that time were put aside to fight and "liberate the homeland, expelling the Portuguese and those who helped perpetuate the colonial system in the area". It underscores the "prowess" of the Barue rebellion, emphasising that its defeat was only possible following Portugal's alliance with "angoni mercenaries", who "impos[ed] much terror to the orders of the colonial governor". Besides this most prominent case of anti-colonial resistance in the country, the textbook refers to the strike in Lourenço Marques, unprecedented in the history of the labour movement, that took place in the same year within the context of war-related famine and inflation and which was violently suppressed. ${ }^{77}$

\section{A nation divided: Between loyalty and resistance}

While the Namibian and Mozambican textbooks mentioned above emphasise the unity of local populations in their struggle against colonial rulers during WW1, one textbook in Cameroon indicates a difference in the position held by various local communities at the time, explaining that "the various tribal groups in Cameroon that were either allies or enemies of the Germans before 1914 found themselves fighting either for the Germans or for the Allies". The author emphasises that this difference of position among Cameroonians meant that "during battles, indigenes were killing indigenes on the enemy side", thus adding to the tragedy of this war for the local population. ${ }^{78}$

76 NM5:66 (See code Table 1).

77 MOZ1:20-23 (See code Table 1). The textbook also refers to miners' strikes in South Africa that took place against the backdrop of WW1.

78 CM1:51(See code Table 1). 


\section{The war aftermath: The effects of WW1 on Africa}

Having outlined the causes and course of WW1, the textbooks finally draw attention to the far-reaching consequences of this war on Africa and its people, both socio-economic and political.

\section{Socio-economic consequences}

The textbooks highlight, first of all, the cost of a war that was imposed on the continent. They stress the massive loss of life of native people, both soldiers and civilians, although few estimates are provided of African victims of fighting, famine, and disease. A passage in a Congolese textbook is particularly telling of the human cost of the war. After mentioning the victory of the Allies over Germany, the authors affirm that "this victory was won at the price of enormous suffering endured by the African people. ... Many were killed, the survivors returned injured, mutilated". ${ }^{79}$

As part of their depiction of the human costs of the war, several textbooks mention the displacement, and the consequent separation of families, caused by WW1. The Rwandan teacher guide, for instance, explains that many had left their villages "for fear of missiles and to run away from the obligation and burden of carrying war materials" ${ }^{80}$ A Kenyan textbook briefly refers to people's flight from imposed conscription in a section on the biography of Kenya's first president, Jomo Kenyatta, who, in his early life, had "escaped from the forced recruitment" imposed by the British on his community, the Agikuyu, by taking refuge among the Maasai. ${ }^{81}$

Various textbooks further draw attention to the material costs of the war and the consequent beginning of a period of "crisis for African economies". ${ }^{82}$ They mention the widespread destruction of property and facilities, including homes, schools, hospitals, farms, and roads, ${ }^{83}$ as well as the decrease of production suffered in the colonies due to the burning of farms, plantations, and mines, and to the recruitment of Africa's most active population, which

79 DRC2:165-166 (See code Table 1).

80 RW2:75 (See code Table 1).

81 KN1:146 (See code Table 1). One Cameroonian textbook refers to a special case of displacement during the war in the country, where thousands among the "strong German supporters such as Charles Atangana alongside many Beti Chiefs, escaped with the Germans to Fernando Po" just before the colony surrendered. CM1:52 (See code Table 1).

82 CI1:66 (See code Table 1).

83 One Namibian textbook, for instance, indicates the destruction inflicted by retreating German troops in Namibia, stressing that "as the German troops fell back, they poisoned the water points and blew up the railway lines" in order to prevent the enemy from using this crucial infrastructure. NM1:105 (See code Table 1). 
was sent to the war front, in combination with reduced volumes of African export to Europe due to the latter's decline. ${ }^{84} \mathrm{~A}$ few textbooks mention serious food shortages as one of the gravest consequences that derived from the destruction and decrease of production, and which had caused many deaths across Africa. Rwandan textbooks refer to the "terrible" Rumanura famine, which had been provoked by the destruction and the suspension of cultivation "by the order of the German command in order to deny cover to [the] enemy". ${ }^{85}$ The Sierra Leonean textbook, for its part, mentions the great frustration among the colony's population due to the food shortage and the consequently increased price of basic necessities following the massive conscription of young farmers. ${ }^{86}$ According to a Tanzanian textbook, WW1 had also resulted in a more "intensive exploitation of the African people ... to overcome war losses" in Europe. African people had been reportedly subjected to "more forceful taxation and forced labour" and increased "land alienation". The book explains that "many people lost land which was given to the whitemen in order to grow cash crops needed highly in Europe to build their economies". The author mentions the example of the so-called soldier settler scheme in Kenya, "which encouraged the white soldiers to occupy land and set up farms" ${ }^{87}$

While elaborating on the substantial material costs of the war suffered by African colonies, some textbooks recognise the economic benefits deriving from the war. The author of a Cameroonian textbook mentions the development of local industries during the war (such as the coal industry), and the increased circulation of money in society after the return of African recruits from Europe, who, according to the textbook, "were paid highly". 88

\section{Political consequences}

The African textbooks analysed often outline some of the political consequences of WW1 for the continent. Among them is the new scramble for Africa which took place at the end of the war and which affected Germany's former colonies in particular as it was ratified in the Treaty of Versailles of 1919. The textbooks typically present a list, an overview or a map of the

84 See for example: TZ2:93; CM1:52, 177-178 (See codes Table 1).

85 RW2:75 (See code Table 1).

86 SL1:168 (See code Table 1).

87 TZ2:93 (See code Table 1).

88 CM1:177. On the positive impact of WW1, see also ANG1:43 (See code Table 1). 
division of the territories among the victors of the war on the African Front. ${ }^{89}$ In recounting the redistribution and reorganisation of African territories, several schoolbooks, such as one from Namibia, underscore the undemocratic nature of this action, highlighting that "the indigenous African people of these colonies were never asked their opinion". ${ }^{90}$ A Cameroonian textbook adds that the map of Africa was redrawn in an arbitrary manner, whereby the partition of certain African territories among European powers had separated certain communities, such as the Ewe of Togo. ${ }^{91}$ In the case of Cameroon and Rwanda, the textbooks also mention the territorial losses imposed on the respective country as a result of this new repartition, a seizure portrayed in Rwandan textbooks as an outrageous attack on Rwanda's territorial integrity.

While the war had resulted in the "expulsion of the Germans" from Africa, according to most textbooks the subsequent change in terms of governance did not emerge as hoped for by the African people. The textbooks typically emphasise that, according to the principles of the League of Nations, ${ }^{92}$ the victors, acting as mandatory powers of people who were considered "not capable of governing themselves", ${ }^{3}$ "should not", as pointed out in a primary school textbook from Cameroon, "treat the territories as colonies", but "contribute to the[ir] development ... and lead them to independence".${ }^{94}$ In an indignant tone, one Namibian textbook comments on the Europeans' paternalistic and patronising attitude towards colonised people, arguing that "it was insulting to say that they were not ready for independence" and exclaiming that "the various chiefdoms such as the Herero had been independent chiefdoms for centuries!"95

The textbooks usually suggest that the League of Nations' principles, however condescending, had not been respected as expected by the colonies. Textbook descriptions of the nature of governance in the aftermath of WW1 commonly underscore a general dissatisfaction in the colonies with a continuation or even a worsening of the previous state of affairs under German rule. This criticism is found in textbooks from all former German colonies.

89 The fate of Ruanda-Burundi after the war is often forgotten in textbook narratives across Africa.

90 NM5:67 (See code Table 1).

91 CM1:177 (See code Table 1).

92 With regard to the League of Nations, reported views vary, from its establishment being understood as "the most positive achievement" of the peace settlement, as suggested in a Cameroonian textbook (CM1:289), to this institution being described as a mere "instrument for the defense of the interests of the victorious powers", as found in a Mozambican textbook (MOZ1:41) (See codes Table 1).

93 RW2:85 (See code Table 1).

94 CM3:75 (See code Table 1).

95 NM5:67 (See code Table 1). 
A Cameroonian textbook, for instance, stresses the lack of fundamental change after Germany's departure by suggesting that, under the smokescreen of international altruism, the "colonies of the defeated nations ... were seized and administered like colonies by the victorious powers under the cover of the mandate of the League of Nations". ${ }^{96}$ According to the author, what was different, and thereby greatly disrupted the life of Cameroonians, was the establishment of two new systems of administration and education, the introduction of two new dominant languages, the establishment of barriers to trade and freedom of movement, and the division of ethnic groups as a result of the partition of the territory by France and Britain after the war. ${ }^{97}$ Similarly, a Tanzanian textbook, after having explained that during the war the Germans had been "forced out and replaced by the British", affirms, without providing much detail, that "the British colonial government did not differ very much from that of the German colonial government". ${ }^{98}$

In Rwanda, the tone in relation to the de facto substitution of colonial masters in the country appears particularly virulent. One textbook explains that, following the country's military "conquest" and "occupation" by Belgium, during which Rwanda was subjected to a military regime which enforced food requisition and the recruitment of people as carriers, colonial domination had continued under the Mandate period, during which Belgium had officially become Rwanda's "Trustee". 99 A Rwandan primary school textbook comments that, "Trustees were supposed to rule their territories for the benefit of the local people. They were also supposed to be preparing the territory for independence. The Belgians did neither of these two things." 100

Another Rwandan textbook refers to the introduction of "cruel" forced labour by the new rulers, unequivocally adding that, "during Belgian colonial rule, the White man was the absolute master and the Black man was the slave and the servant". ${ }^{101}$ It also points to a "very bad" relationship between the "occupying authorities" and the Rwandan royal court, arguing that the Belgians, who had engaged in a "progressive tearing apart of the monarchy", "had never liked [King] Musinga", among other things because "he had fought alongside the Germans against them" during WW1. ${ }^{102}$

\footnotetext{
96 CM1:288 (See code Table 1).

97 CM1:54-55 (See code Table 1).

98 TZ1:4 (See code Table 1).

99 RW3:81, 84 (See code Table 1).

100 RW1:46 (See code Table 1).

101 RW3: 87 (See code Table 1).

102 RW3:82, 87 (See code Table 1).
} 
In Namibia as well, the dominant narrative found in the textbooks negatively assesses the post-war political transformations experienced in the colony. Namibian textbooks describe in detail the conditions under which South Africa administered the country after having fought and defeated German troops there on behalf of Britain. They thereby emphasise, in a typically emotive tone, South Africa's failure to fulfil its obligation towards the Mandate and point to the worsened situation of Namibians as a result of this political change brought about by WW1. One textbook underscores that "the League of Nations expected South Africa to govern South West Africa for the benefit of all of the inhabitants", but that "the reality ... turned out to be very different". ${ }^{103}$ The authors of another Namibian textbook indicate among such expectations a commitment on the part of the mandatory power to "improve the economy and living standards of everyone living in Namibia", "not to dominate or exploit Namibia", and to "prepare the country for independence". ${ }^{104}$ Assessing South Africa's performance in fulfilling such obligations, yet another Namibian textbook argues that "South Africa's mandate over South West Africa did not significantly improve matters for the indigenous people overall, and in many respects it actually made matters considerably worse". ${ }^{105}$ One book explains that, in its report to the League of Nations ("the Blue Book"), "South Africa described how badly the Germans had treated the local people. The Blue Book on Namibia created the impression that things would be different under South African rule. People would get back their land... Instead, South Africa ruled Namibia as if it was part of South Africa. Rather than giving people land, the South Africans took more land from Namibian community". ${ }^{106}$

Along similar lines, yet another textbook bitterly affirms that, "The South African government never intended to free the Namibian people from colonial rule. From the very beginning its aim was simply to replace German colonial rule with its own. It never made any attempt to right the wrongs done by the Germans ... it continued the oppression and exploitation that the Germans had introduced and added new exploitative measures." 107

This textbook speaks of South Africa's "absolute", "oppressive”, "unfair", "harsh", and "cruel" rule. ${ }^{108}$ The Namibian textbooks all draw considerable

103 NM1:105 (See code Table 1).

104 NM3:59 (See code Table 1).

105 NM5: 69-70 (See code Table 1).

106 NM3:59-60 (See code Table 1).

107 NM4:47 (See code Table 1).

108 NM4:44, 52, 53, 55 (See code Table 1). 
attention to the increased land expropriation and the forced removal of Namibians in favour of white settlers, the establishment of racial segregation through an expanded reserve system and a strict control of movement of the indigenous population, which was confined to underdeveloped areas, and the encouragement of a system of migrant contract labour. ${ }^{109}$ They explain that any resistance was violently quashed. One textbook takes again the example of rebellious Herero, whose "dwellings were set on fire, their cattle confiscated and their crops burnt". ${ }^{110}$ Having provided such information, one of the activities foreseen in the various textbooks with the objective of developing empathy asks pupils to imagine how they would feel about the Mandate and about South African rule in their country if they were living in Namibia in that era. ${ }^{111}$ They also encourage pupils to understand the legacy of racial segregation in the area where they live today, and to reflect on how Namibia would have looked nowadays if it had not experienced German and South African rule. ${ }^{12}$

Not dissimilarly from former German colonies, textbooks from countries that had fought on the side of the Allies, such as Francophone West Africa, DR Congo and Sierra Leone, highlight the deep disappointment of the colonial subjects with the lack of improvement in their life in the colony despite their "meritorious" 113 effort in the war and the great sacrifice they had made to support the colonial masters in their darkest hours. The textbook by Hatier describes the loyalty demonstrated by "black soldiers" as a testimony of their confidence in a prospect of "softened" colonial regime which they would gain in return. ${ }^{114}$ It highlights that this hope, however, was soon trampled when these soldiers failed to receive the expected benefits in the wake of the war. ${ }^{115}$ A Tanzanian textbook stresses that colonial recruits were in fact "oppressed and disregarded when they got home". ${ }^{116}$ Similarly, the Sierra Leonean history book underscores that colonial subjects had been left disillusioned and embittered after the war. Its author explains that Sierra Leoneans had supported the European war effort "in the hope that they would be given a greater say in the management of their own affairs after the end of the war" - a hope "heightened by the principles of liberal democracy and self-

109 NM1:105-106; NM3:61-68; NM4:52-65; NM5:69-72 (See codes Table 1).

110 NM5:71 (See code Table 1).

111 NM3:59 (See code Table 1).

112 NM4:64 (See code Table 1).

113 ANG1:50 (See code Table 1).

114 CI1:66 (See code Table 1).

115 CI1:68. See also ANG1:40 (See codes Table 1).

116 TZ1:13 (See code Table 1). 
determination propounded by President Woodrow Wilson of the USA and Prime Minister David Lloyd George of Britain". ${ }^{117}$ The author comments that, "after the war, however, the British Government put political questions aside and instead concentrated on the economic exploitation of the African colonies". The Congolese textbooks, for their part, suggest that, although life had improved to some extent after WW1, particularly in the domains of education and health, colonial policies had continued to "ignore the freedom of the individual", persisting in subjecting Congolese people to strict control of movement to support a project of racial segregation, the disrespect of which was severely punished with forced labour. ${ }^{118}$

In relation to political issues, the textbooks also widely highlight the deep impact of the war experience on the growth of African nationalism and the struggle against colonial rule. They portray WW1 as having shaken colonialism worldwide, and specifically across Africa, by laying bare the fallible and "the inhuman character of the so-called civilized", ${ }^{119}$ as well as by favouring an awakening among colonised people as a result of the suffering imposed by the war and a consequent revival of local anti-colonial resistance movements and revolts - uprisings which, according to a Congolese textbook, were repressed "to the uttermost". ${ }^{120}$ According to a Cameroonian textbook, this "spirit of self-realisation" among Africans had resulted in attempts "to bring back the dignity and the pride of Africans after several centuries of abuse". ${ }^{121}$ The textbook by Hatier points out that "the war had made the white men lose their prestige and the myth of their invincibility", concluding that, "in this sense, WW1 was a major turning point in the history of Black Africa". ${ }^{122}$ Similarly, a Namibian textbook argues that "people now saw that Europe was not superior to the rest of the world" and not therefore entitled "to force European culture and rule on the colonies". ${ }^{123}$ A new era had dawned in Africa.

\footnotetext{
117 An Angolan textbook emphasises the general disappointment felt across Sub-Saharan Africa with the contradictions and inconsistent application of this principle worldwide as manifested in the gaining of independence by a group of Arab countries in Northern Africa. ANG1:41 (See code Table 1).

118 DRC1:130-131; DRC2:168 (See codes Table 1).

119 ANG1:41 (See code Table 1).

120 DRC2:166 (See code Table 1).

121 CM1:179 (See code Table 1).

122 CI1:68 (See code Table 1).

123 NM1:3 (See code Table 1).
} 


\section{Discussion}

The analysis of African textbooks and their dealing with WW1 presented in this article offers a window on the place of WW1 in African public memory and on the specific knowledge, skills, values, and attitudes considered important in contemporary African societies when teaching younger generations about this watershed in history. Above all, the analysis showcases efforts, found across African textbooks, to re-claim and re-centre local historical agency, experiences, and views, while also pointing to the possibility to better valorise and preserve this part of national, African and world heritage - too often neglected and marginalised.

The analysis provided illustrations of efforts made within African education systems to assert Africa's integral place in history and to advance an understanding of the world among pupils which involves an appreciation of this continent's past and its contributions to world history and civilisation. It showed examples proving a determination shared by African societies to thus transmit knowledge that challenges the inadequacy of a predominantly Western-centred historiography, which postcolonial theories have long brought attention to in their criticising of a traditional treating of Africa, and the non-Western world in general, as peripheral or outside mainstream historical analysis. In their challenging of traditional paradigms, textbook narrations of WW1 appear to simultaneously fulfil an important political and social function as they were discovered to widely celebrate African nationalism. The analysis found the narratives of World War I reported in African textbooks, though meagre, to be generally framed within a nationalist and anti-colonial discourse inscribed in a nation-building project to which schools across the young post-colonial African states tend to subscribe. ${ }^{124}$ The textbook narratives of WW1 exhibited a common vocabulary of bravery, sacrifice, and enormous suffering and loss, at times showing nationalist and Africanist overtones and evoking strong emotions, including a sense of victimhood at the hands of former colonial rulers combined with feelings of national and African pride and anti-colonial sentiments, factors which appear central in promoting collective identities.

In identifying these trends, the analysis also calls attention to the limits of teaching such grand-narratives, arguing that the necessary re-claiming of African experiences and views of WW1 in contemporary textbooks, though

124 D Bentrovato, "Narrating and teaching the nation: The politics of history, identity and education in the Great Lakes Region of Africa”, Ph.D, Utrecht, University of Utrecht, 2013. 
empowering in its distancing from Eurocentric perspectives, appears, however, to continue disempowering young Africans by predominantly aligning to what the father of critical pedagogy, Paulo Freire, refers to as "banking education", namely a type of education based on the top-down transmission of dogmatic knowledge - widely observed in this study and which Freire considers an oppressive instrument of manipulation and domination used to reinforce hegemonic structures and people's feelings of dependence and passivity. ${ }^{125}$ The study points to a prevalent reality whereby current approaches to teaching history have largely come at the expense of a critical methodology able to encourage pupils' reflection on the past and its legacy in the present, and to broaden perspectives and challenge single and Manichean narratives of glorification and victimisation, the downsides of which are notoriously known in history. ${ }^{126}$ In this respect, as this study illustrated, South Africa, especially, represents an exception. Its textbooks were found to offer a critical appraisal of WW1 through an analysis of sources, evidence, multiple perspectives, and histories from below, and through exercises in historical thinking, prompting pupils to gain a deeper understanding of the past and of current realities to help younger generations shape the future. Of particular notice are the efforts made in South African textbooks to ensure the significance of history for young people's lives, notably through their use of the study of WW1 as an entry point for discussions on conflict and human rights, two topics which are of great relevance for Africa and for the world today. Ostensibly, it is such practices which promise to teach important and meaningful lessons for posterity in a world which continues to be threatened by perpetual wars and large-scale injustice and abuse.

\section{Conclusion}

This article, written as we commemorate World War I, offers an opportunity to reconsider current trends in the ways in which we teach about one of the most tragic events of human history, and to reflect on promising orientations and directions for the future. Above all, the analysis pointed to a widespread asserting of local historical experiences and perspectives in African textbooks as integral part of an apparent generalised wish to provide younger generations with a "usable past" which could nourish a sense of collective identity and memory, and of ownership over history. At the same

125 P Freire, Pedagogy of the oppressed (New York, Herder and Herder, 1970).

126 On the worldwide perilous politicisation of history and of its teaching, see among others, M Ferro, The use and abuse of history, or how the past is taught to children (London, Routledge, 2003). 
time, the analysis pointed to lost opportunities to use the study of WW1 to teach deeply meaningful lessons that could foster historical understanding, critical thinking and multiperspectivity. Such lessons have a critical potential of effectively empowering young people to become active participants in their own learning while also preparing them to constructively respond to contemporary societal challenges. In this respect, more concerted efforts could be made to allow for possibilities of using the study of WW1 to promote much-needed understanding and questioning of war and war-making, and their causes and impact. Similarly, the study of WW1 could provide more opportunities to foster intercultural dialogue and understanding, for instance by strengthening pupils' ability to discern links and parallels between wartime experiences in Africa and other regions of the world, as well as among African regions themselves, making explicit connection and comparison that elucidate commonalities, distinctions, linkages and interactions at the local, regional and global level. Undoubtedly, such and other lessons are opportunities that we, as educators, should nurture and cherish at a time where the need for dialogue and peace remains ever-great. 